【カテゴリーII】

鉄筋コンクリート補強された歴史的煉瓦造建造物に生じる白華現象のメカニズム 一煉瓦中の含水量が白華現象に及ぼす影響—

\title{
MECHANISM OF EFFLORESCENCE ON HISTORICAL BRICK MASONRY BUILDINGS REINFORCED WITH CONCRETE
}

-Influence of water content in brick on efflorescence-

松尾隆士*, 田中享二**, 石㟝武志***

Takashi MATSUO, Kyoji TANAKA and Takeshi ISHIZAKI

\begin{abstract}
It is indicated that the reinforcement with concrete causes efflorescence and decay of brick because of alkali salts in cement. This paper explains the mechanism of efflorescence on historical brick masonry buildings reinforced with concrete. First, accelerated test method was developed so as to reproduce efflorescence on brick masonry wall reinforced with concrete. Second, we investigated relation between water content and rate of evaporation. It is considered that water did not move in a liquid condition in the brick below the water content of $4 \sim 5 \mathrm{Vol} \%$. Finally, model wall specimen similar to actual historical brick masonry wall was made and accelerated test was carried out. And water content of each brick was continuously measured by TDR(Time Domain Reflectometry) method during the test. It is concluded that efflorescence did not occur $4 \sim 5 \mathrm{Vol} \%$ water content below because movable water in liquid phase was not present in the brick.
\end{abstract}

Keywords : Brick Masonry building, Reinforced Concrete, Efflorescence, Conservation, Water content 棟瓦造建造物，鉄筋コンクリート，白華現象，保存，含水量

\section{1. 序論}

我が国では煉瓦造建造物が明治時代から大正時代までの間に数多 く建設された。それらの中で建築的価值の高い建造物は全国に約 500 棟現存すると言われて扔り 1)その多くは保存・活用の対象と なる可能性が高い。技術的な側面から歷史的建造物の保存・活用を みると、建物の歴史的な価值を保ちながら、活用計画に適する安全 性を確保しなければならない。個々の建物によって保存す心゙き内容 が異なるため、保存・活用計画に適した技術を選択できるように、 保存技術に関する情報を設計者や技術者に提供しておくことが重要 であると思われる。

棟瓦造建造物に関して言えば、耐震性に劣るため保存・活用する 場合には多くの場合構造補強が必要になる。その構造補強には、コ ンクリート、鉄骨・鉄板、合成樹脂、高強度繊維など様々な材料が 用いられている。鉄筋コンクリートによる補強では壁、柱、卧梁、 スラブなどを新設し棟瓦壁体と一体化する方法がとられる。そして、 鉄筋コンクリートは煉瓦壁体と力学的な剛性が近く、補強効果を期 待できるため数多くの補強事例がある。しかし、鉄筋コンクリート による補強を行った場合、施工後に煉瓦壁体表面に顕著な白華現象
が生じ、美観上問題や棟瓦自体の劣化を引き起こすことが指摘され ている2。

本研究は以上のような背景のもと、棟瓦壁体中の含水量が白華現 象に与える影響に関して定量的に考察することを目的とする。その ため、具体的には白華現象考再現寸るための試験方法について検討 し、さらに煉瓦の含水量変化を測定することで白華現象のメカニズ ムを明らかにすることを目的としている。

煉瓦造建造物の白華現象に関しては、欧米を中心に白華現象に関

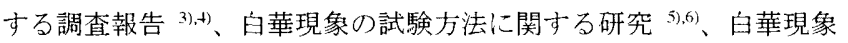
に関する論評 7),8)、白華現象を屋外環境で再現した実験報告 ${ }^{9}$ など 数多くの研究がなされてきた。特に、補強材からの白華現象に関し ては、Young, J.E が主にコンクリートブロック補強した棟瓦壁体に 関して検討在行い、補強材の可溶塩類が白華現象の原因となること を実験的に示している ${ }^{10}$ 。

白華現象は特に水分量と密接に関倸寸ることから、実際に鉄筋コ ンクリート補強するとき、その防止対策を設計の段階から講ずるに は、棟瓦壁体の含水量の観点からのメカニズムの解明とその定量的 な評価が必要である。この観点からの研究はまだ十分とは言えない。
$*$ 東京工業大学大学院 大学院生・工修

** 東京工業大学建築物理研究センター 教授・工博

*** 東京文化財研究所 保存科学部長 - 理博
Graduate Student, Tokyo Institute of Technology, M. Eng.

Prof., Structural Engineering Research Center, Tokyo Institute of Technology, Dr. Eng.

Director, Conservation Science Department, National Research Institute of Cultural Properties, Tokyo, Dr. Sc. 
2、鉄筋コンクリート補強された歴史的棟瓦造建造物の問題点

\section{1 鉄筋コンクリート補強の種類}

歷史的棟瓦造建造物老鉄筋コンクリート補強する場合、一般的 に柱、梁、壁、スラブなどを新設し、それらと棟瓦壁体とをアン カ一などを用いて一体化する方法がとられる。鉄筋コンクリート による補強方法を分類すると図 1 のようになる。棟瓦壁体の内側 に鉄筋コンクリート壁を増打寸る力法は、古くから行われてきた 補強方法であり、十分な補強効果を期待でき、さらに防災上有利 となるが、内部空間の保存が困難となる。卧梁、スラブを新設す る方法は棟瓦壁体を一体化する効果が高く、補強効果を期待でき るが、オリジナルの屋根や床との共存が難しいという久点がある。 バットレスによる補強は内部への摃傷はないが、外部意质に影響 を及ぼすため適用には注意が必要である。また、棟瓦壁体の一部 を满状に削り取り、鉄筋老設置してからモル夕ルを充填して一種 の鉄筋コンクリート柱を形成与る補強方法も行われている。

以上の上うに、様々な補强方法が存在寸るが、いずれの方法で

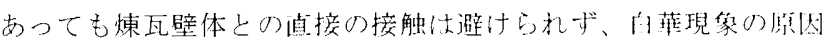
となることが予想される。

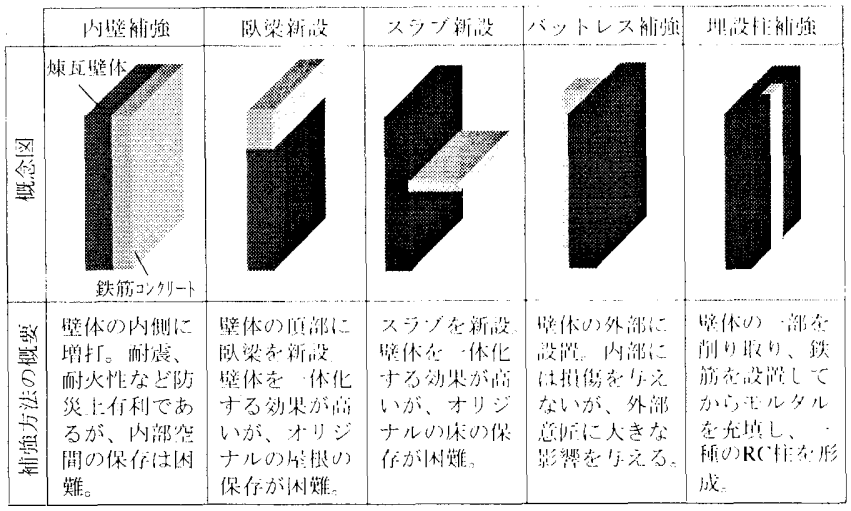

図 I 鉄筋コンクリート補強の概要

2. 2 鉄筋コンクリート補強された歴史的棟瓦造建造物の一例 鉄筋コンクリート補強された歷史的煉瓦造建造物け白鞋現舜を 確認寸るため実際に目視に上る調査を行った。対象としたのは1890 年に竣工し、1977 年に鉄筋コンクリートに上る内壁補強が施され た建物である。寒施された補強の断面詳細図を図 2 に示寺。

白華現象の状況を写真 1 、写真 2 に示寸。壁面全体に白華現象が 見られたが、特に 1 階壁面と比較すると 2 階壁面の白華現象が顥 著である傾向が見られた。これは、既往の研究報告 ${ }^{8}$ に記述され ているように壁体の上部の方が下部よりも濡れやすくなる傾向が あることが要因であると思われる。また、2 階の既存棟瓦壁体の 壁厚が 1 階のそれより薄いことも要因と思われる。しかし、2 階 壁面の白華現象が頙著となる傾向については一つの建物の状況で あり、他の事例を調査するなど、さらに検討を要すると考えられ る。次に、部位ごとに見てみると、壁面の取り合い部分、軒下、 軒蛇腹の周辺部、空枠の下部など雨水で濡れや寸いと考えられる 部分の白華現象が㪟著であった。壁体が濡れることで、鉄筋コン クリートと棟瓦が接触した筒所に扔いて、セメント塩類が溶解し 棟瓦内部に移動するため白華現象を引き起こしたと考えられる。

したがって、含水量の観点から白華現象のメカニズムを定量的
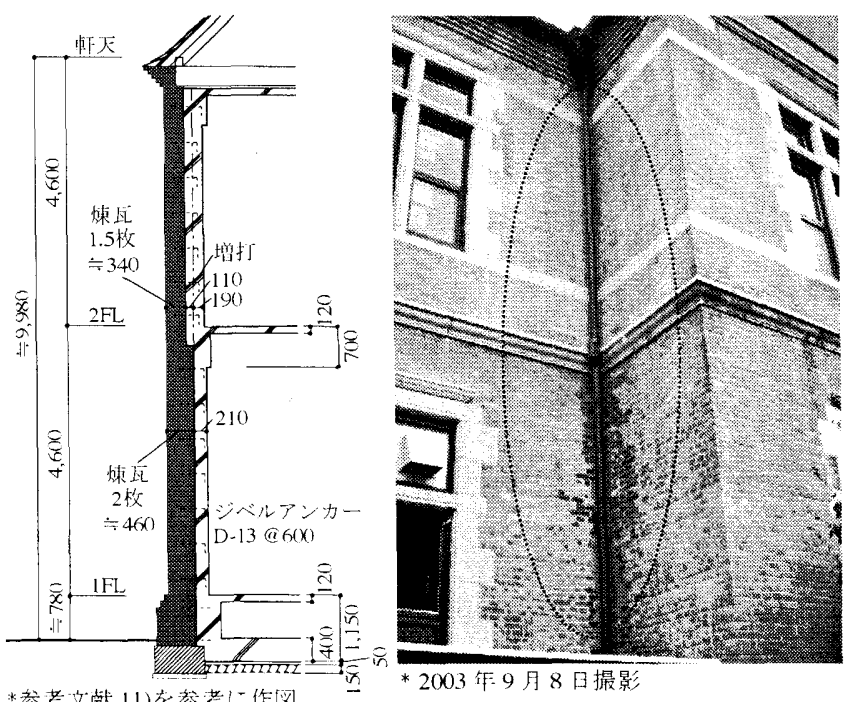

図 2 断面詳細図

写真 1 壁面の取り合い部の白華現象

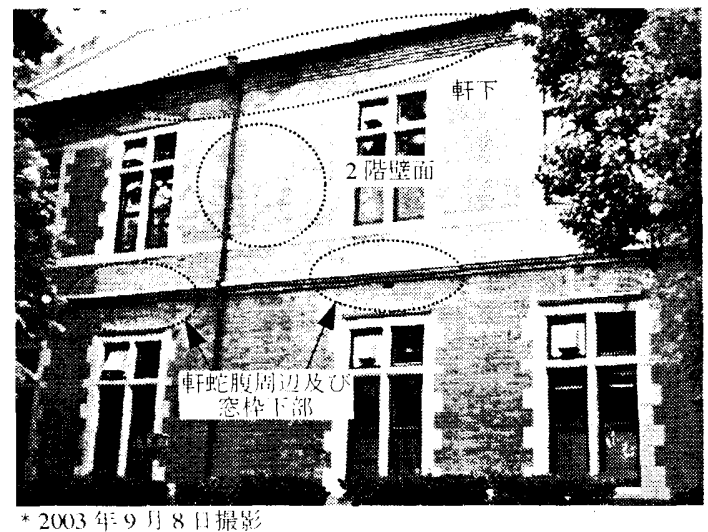

写真 2 白華現象が顕著に観察された部位

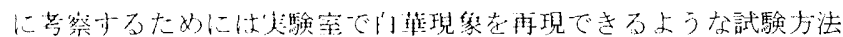
が必装である。

\section{3. 促進試験方法の検討}

3. 1 試験体の製作

煉瓦壁体に生じる日華現象を実験室で再現し、観察するための促 進試験方法について検討した。そのため、図 3 に示扵ように普通棟 瓦の一面安セメントモルタルで補強した試駼体を製作した。この試 験体は、一面を煉瓦とした型枠にセメントモルタル在打設したもの である。な拉、セメントモルタルを打設する際は、棟瓦とセメント モルタルとの接着性を良くするため煉瓦に 30 分閒水湿しを行った。 使用したセメントモルタルの調合は、セメント：砂＝1:2.5、水セ メント比 $60 \%$ とした。
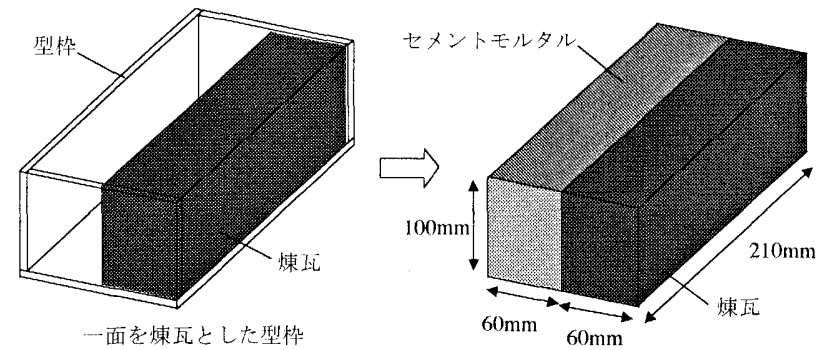

図 3 試験体の概要 


\section{2 水分の供給方法の検討}

図 3 の試験体を用いて、白華現象を観察导るための促進試験に関 して検討を行った。ここでは、特に白華現象と密接に関倸のある水 分について、その供給方法と乾燥方法を検討した。図4 亿促進試験 として検討した方法の概念図とその結果を示卞。

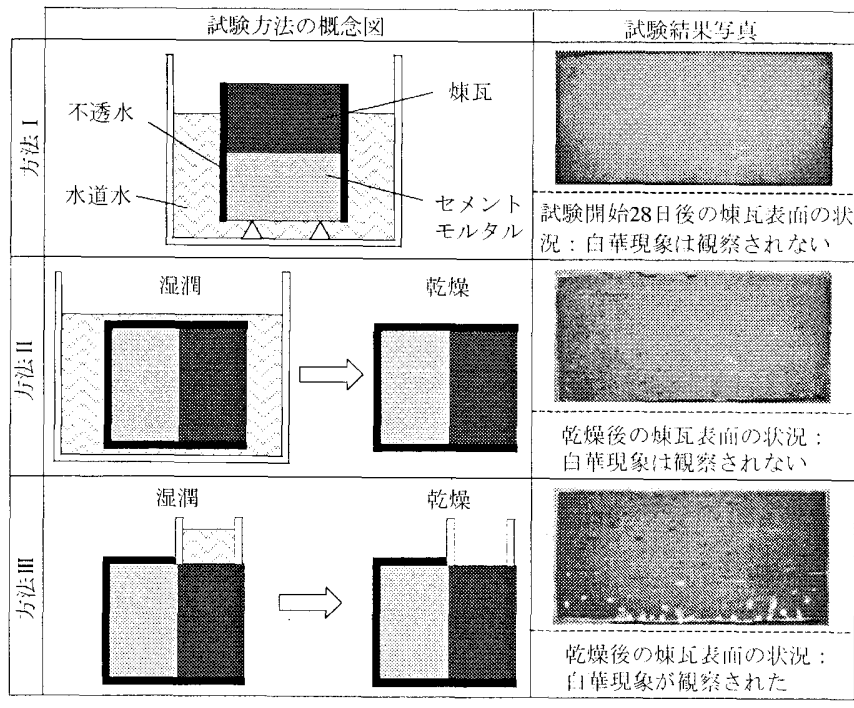

図 4 試験方法の概念図と試験結果

方法 I では試験体を水槽に煉瓦面を上にして浸漬させ、白華現象 老観察した。方法凹では試験体を水中に浸漬し湿潤状態にした後、 気中にて乾燥させ白華現象を観察した。方法IIIでは試験体上面に設 置した水溜に水を入れ湿潤状態にした後、水溜の水がなくなり、観 察面が乾燥してから白華現象老観察した。なお、試験は寸心゙て $20^{\circ} \mathrm{C}$ の恒温室内で行った。

方法 I では、セメントモルタルの透水性が低く、棟瓦まで水が浸 透吉るのに長時問要するため、試験開始から28日経過しても白 華現象は観察されなかった。方法Пでは、ほとんど白華現象老観察 することができなかった。方法では、特に棟瓦表面の下部に白華 現象が観察された。

以上の検討結果から、促進という観点からは最も短時間で白華現 象を観察できた方法IIIの方法により促進的に白華現象を再現できる と考えられた。

\section{4、白華現象を再現するための促進試験 \\ 4. 1 促進試験の概要}

前章の検討結果をふまえ、さらに湿潤と乾燥のサイクルを繰り返 して白華現象を観察した。試験体は前章と同様の方法で製作した。 試験体に使用した棟瓦の吸水特性とセメントモルタルの調合を表 1 に示す。

試験概要を図 5 に示す。試験体の観察面上上面の棟瓦面以外に工 ポキシ樹脂を塗布し、上面の煉瓦部分からのみ水が浸透するように した。試験では水道水を試験体上部の水溜に注ぎ入れ、24 時間湿 潤状態にした後水溜の水を抜き、72 時間乾燥させた後白華現象を 観察した。試験中は水溜に蓋をして観察面からのみ水分が蒸発する ようにした。これを 1 サイクルとして繰り返し 10 サイクルまで観 察を行った。な执、試験は $20^{\circ} \mathrm{C} 、 60 \% \mathrm{RH}$ の環境下で行った。
表 1 試験体の条件

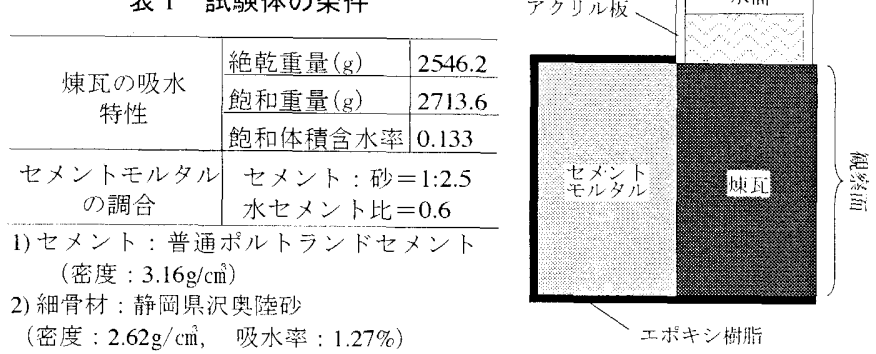

3) 飽和重量 : 24 時間冷水に浸漬後の重量

図 5 促進試験の概要

\section{2 促進試験結果}

試験結果之 2 値化処理を施した画像を写真 3 に示寸。また、この 2 值化画像から棟瓦面に対寸る白華面積率を計算した結果在図 6 に 示古。

サイクルを繰り返すごとに、白華現象が顕著となる様子が観察さ れた。この試験結果から棟瓦の湿潤乾燥の繰り返しを行う試験方法

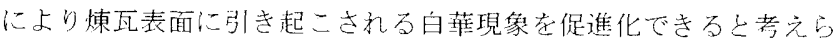
れた。

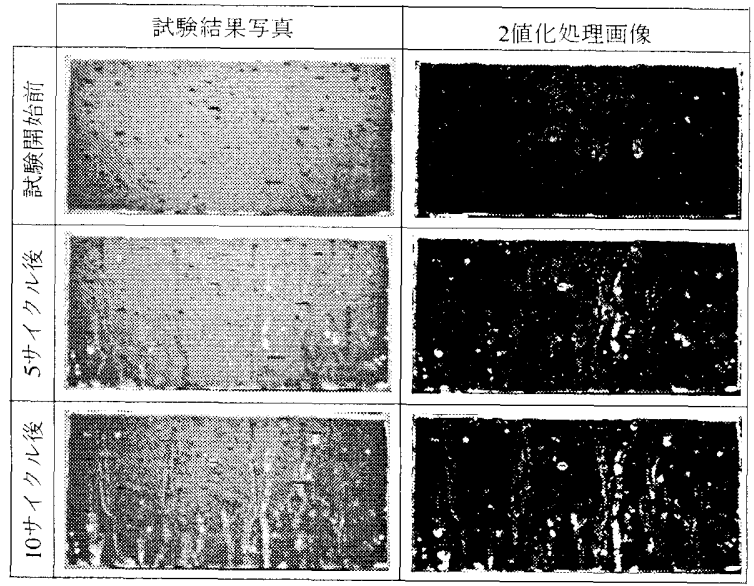

写真 3 促進試験結果と 2 値化処理画像

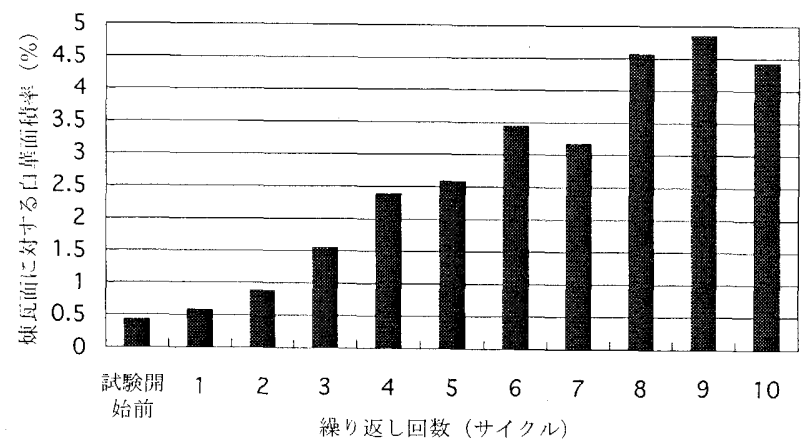

図 6 白華面積率の変化

4. 3 棟瓦の含水量からみた白華現象のメカニズム

試験結果からコンクリート補強された棟瓦壁体に生じる白華現象 に関して以下のような基本的メカニズムが考えられる。

まず、棟瓦が湿潤状態になると煉瓦に接触したセメントモルタル 中の塩類が溶け出し、棟瓦内部を移動し始める。やがて、棟瓦表面 に達する。このときは煉瓦表面の含水率が高いため白華現象として は観察されにくい。その後、乾燥状態になると水分は煉瓦表面から 
蒸発し始める。棟瓦表面が乾燥すると、棟瓦内部の水分がセメント モルタルとの界面から煉瓦表面に向かう力向に移動し、同時に塩類 も表面に移動寸る。さらに乾燥が進むと、棟瓦表面に達していた塩 類は結晶化・固着乙白華現象として観察される。この湿潤・乾燥が 繰り返されることで、より多くの塩類が表面に析出することになる。

以上のような、基本的メカニズム考慮すると、煉瓦の含水率が 高くなり、から含水率の変化が大きい棟瓦ほど白華現象が顕著にな ると予想される。なぜなら、含水率が高いほど棟瓦内部に液状水が 多く存在寸るため、相対的に塩類の溶解量恀多くなり、さらに液状 水に溶解している塩類の棟瓦内部での移動が容易になるからである。

したがって、含水量が白華現象に与える影響について定量的に考 察するためには、棟瓦の含水率変化を測定し、さらに煉瓦内部の水 分移動形態について考察することが必要である。

\section{TDR 法による煉瓦の含水率測定 \\ 5. 1 TDR 法の原理}

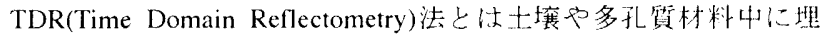
設されたプローブに高周波電磁バルスを与た、その伝搬速度から請 電率を求めてそれらの水分量老算出与る方法である。この測定法什 水の誘電率 $(\varepsilon \doteq 80)$ が土壤の誘電䔞 $(\varepsilon \doteq 3 \sim 10)$ や空父 率 $(\varepsilon \doteqdot 1)$ と大きく異なることを利用している。

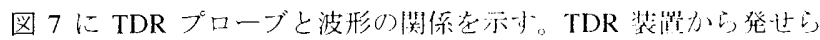
れた高周波電磁バルス注、同軸ゲー・ブルを経由し材料けに埋設され たプローブ内に入り、終端部で片射する。この䦌に、インビーダン スの不整合部で部分的な反射が起こり、か心材料の伝嫴性のために 信号の減衰が起こるためこの上うな波形を示寸。

このとき、プローブ周辺の誘電率を仗次式で求少的る。

$\varepsilon=\left\{c \cdot t_{s} /\left(2 \cdot L_{p}\right)\right\}=\cdots(1)$

ここに、c：真空中の光速 $(\mathrm{m} / \mathrm{s}) 、 \mathrm{~L}_{\mathrm{p}}:$ ブローーブ長 $(\mathrm{m}) 、 \mathrm{t}_{\mathrm{s}}$ : 電磁波 が $\mathrm{L}_{\mathrm{p}}$ を往復する時閒(s)

誘電率が求められれば、体樻含水率 $\theta(\mathrm{cm} / \mathrm{clil})$ は 験式 ${ }^{12)}$

$\theta=\left(-530+292 \varepsilon-5.5 \varepsilon^{2}+0.043 \varepsilon^{3}\right) \times 10^{-4} \cdot \cdot(2)$

により求められる。しかし、より正確に含水率を算出するためには 各材料に対してキャリブレーションを行う必要がある。

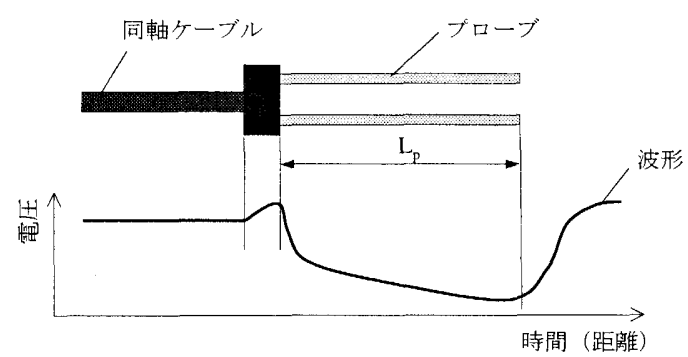

図 7 TDR プローブと波形との関係

5. 2 キャリブレーション方法

煉瓦の含水率を測定するために TDR プローブを製作した。プロ ーブには直径 $3 \mathrm{~mm}$ のステンレス棒を使用し、長さ $50 \mathrm{~mm}$ 、プロー ブの間隔 $10 \mathrm{~mm}$ とした。

製作した TDR プローブを使用しキャリブレーションを行った。 図 8 に試験概要、写真 4 亿試験状況を示す。值径 $50 \mathrm{~mm}$ 、高さ $100 \mathrm{~mm}$
に切り出した棟瓦の上面にドリルで穿孔した後 TDR プローブを挿 入し、棟瓦の誘電率を測定できるようにした。試験では飽和状態（体 積含水率 0.128 ）にした煉瓦を $20^{\circ} \mathrm{C} 、 60 \% \mathrm{RH} の$ 恒温恒湿槽内に設 置し、気乾状態になるまで連続的に誘電率を測定した。また、同時 にはかりで煉瓦の重量変化を測定し含水率を算出した。

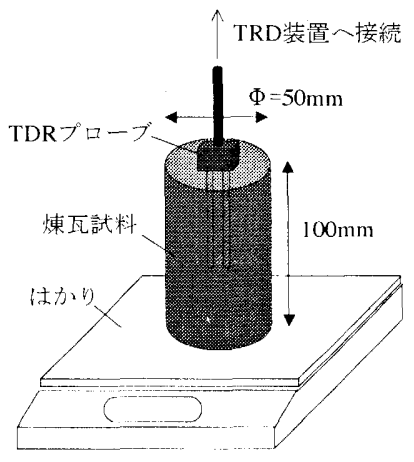

図 8 試験概要

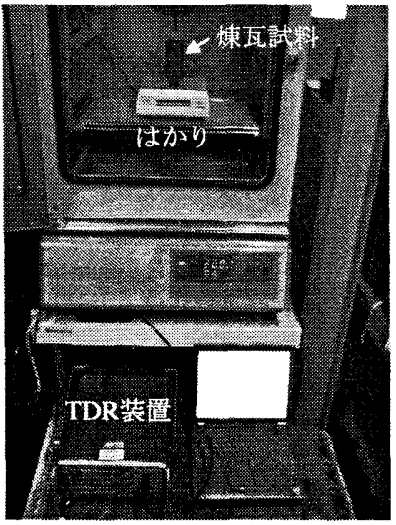

写真 4 試験状況

\section{3 煉瓦の誘電率と含水率との関係}

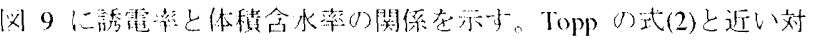

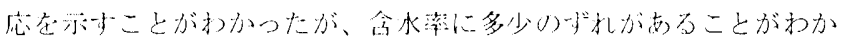

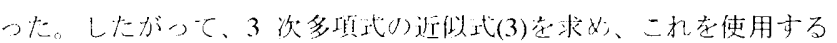
㷄瓦に刘打較正式上した。

$\theta=\left(-776+350 z-5.90 z^{2}+0.0401 \varepsilon^{3}\right) \times 10^{-} \cdot \cdots(3)$

ただし、この較四武は本研究で使用した棟瓦にの为適応できる式 で女り、他の煉瓦に対しては新たに較正式学水める必要がある。ま

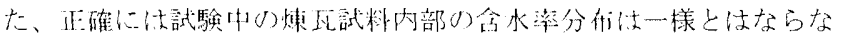
いため、そのことによる誤差がかることを付施しておく。

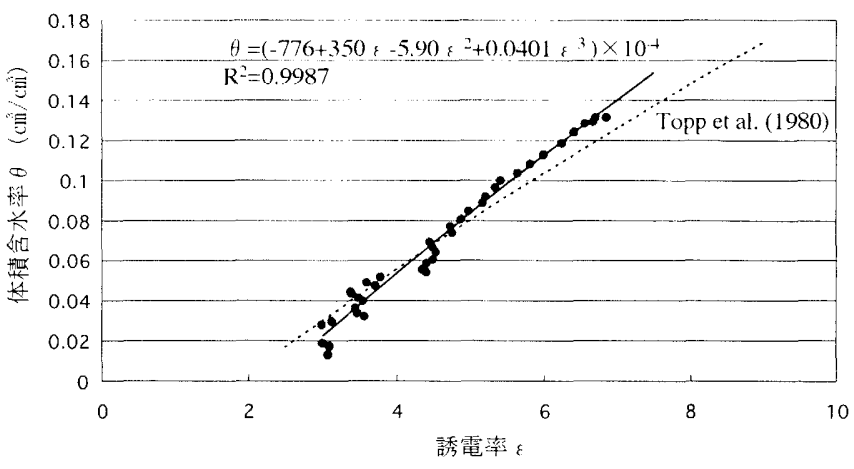

図 9 誘電率と体積含水率の関係

\section{6. 含水率と䗲瓦中の水分移動形態との関係}

棟瓦内部に打いて水分は液状水または水蒸気の状態で移動する。 白華現象の原因となる塩類は溶質として存在するため、煉瓦内部で の水分の移動形態が液状水のときに塩類が移動すると考えることが できる。そこで、煉瓦内部の水分移動形態と含水率との関係に関し て検討を行った。

煉瓦内部の水分移動形態は、棟瓦の蒸発量変化から理解寸ること ができる ${ }^{133}$ 。つまり、含水率が高い場合、表面が乾燥しても内部 の液状水が表面に移動できるため蒸発量は多い。しかし、含水率が 低くなると液状水の移動はほとんど行われなくなり、水蒸気の移動 
が主体となるため、蒸発量はほぼ一定となる。そこで、前章の試験 結果から、蒸発量の経時変化を整理し、さらに含水率の経時変化上 対応させて図 10 に示した。

試験開始直後加蒸発量泣徐々に減少寸るが、約 5 時間後からは 蒸発量はほぼ一定になることがわかる。また、含水率の経時変化と 対応させると、含水率変化が不連続となる点と対応している。この 蒸発量抢よび含水率の変化は、上述のように水分の移動形態の観点 から説明できると考えられる。つまり、試験開始から約 5 時間まで は煤瓦表面が乾燥しても内部の液状水が移動するため蒸発量は多い。 含水率が低くなるにつれて、移動できる液状水の量が減少するため 蒸発量も減少する。そして、約 5 時間を経過すると水蒸気に上る水 分移動が主体となるため、蒸発量はほぼ一定となると考えられる。 したがって、含水率が 4〜 $5 \mathrm{Vol} \%$ 以下になると水蒸気の移動が主体 となるため、塩類移動はほとんど期待できなくなると考えられる。

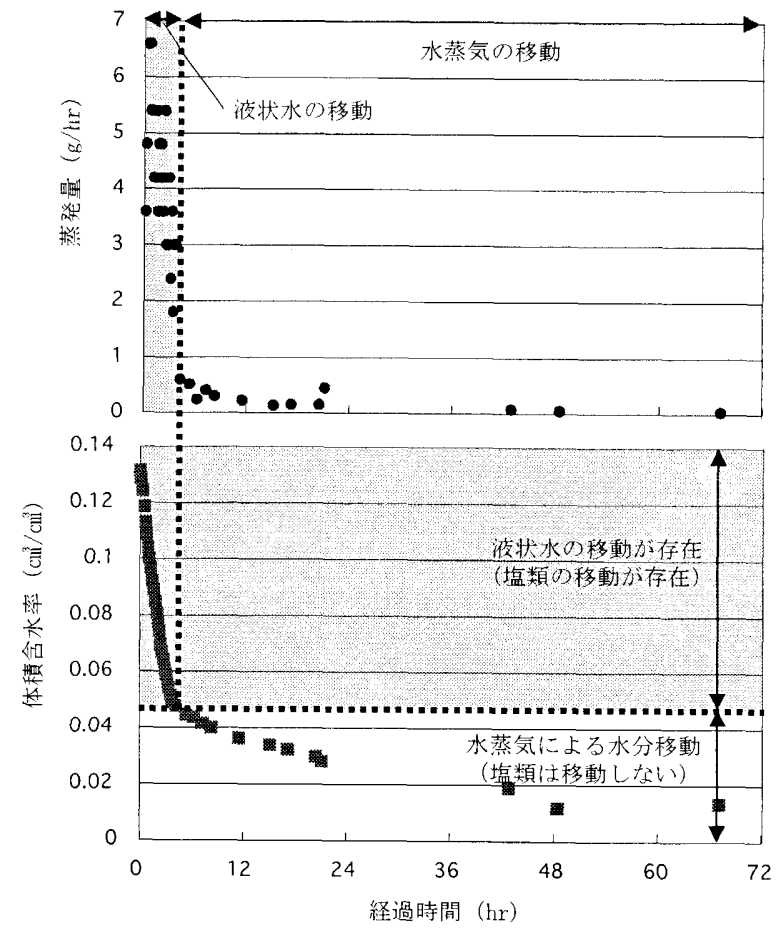

図 10 体積含水率と水分移動形態との関係

7. モデル試験体による促進試験と棟瓦の含水率変化

\section{1 試験体の製作}

これまでの寒験において、白華現象を再現するための促進試験方 法、煉瓦内部の含水率測定と水分移動形態について考察してきた。 しかし、実際の棟瓦壁体法棟瓦と目地から構成されて㧍り、目地が 白華現象に与える影響についても考慮する必要がある。そこで、図 11 に示すような鉄筋コンクリート補強した棟瓦壁体を模擬した試 験体を製作した。試験体㹥㛐積みを行い、20 $\mathrm{C} 、 60 \% \mathrm{RH}$ の環境 下で 28 日間気乾養生した後、一面を棟瓦積みとした型枠にセメン トモルタルを打設し促進試験用の試験体とした。なお、棟瓦積みに 30 分間水湿しを行ってからセメントモルタルを打設した。目地材 料は戦前の日本において多く使用されていたセメント石灰モルタル とした。煉瓦の飽和体積含水率、セメントモルタルの調合、目地モ ルタルの調合を表 2 に示す。
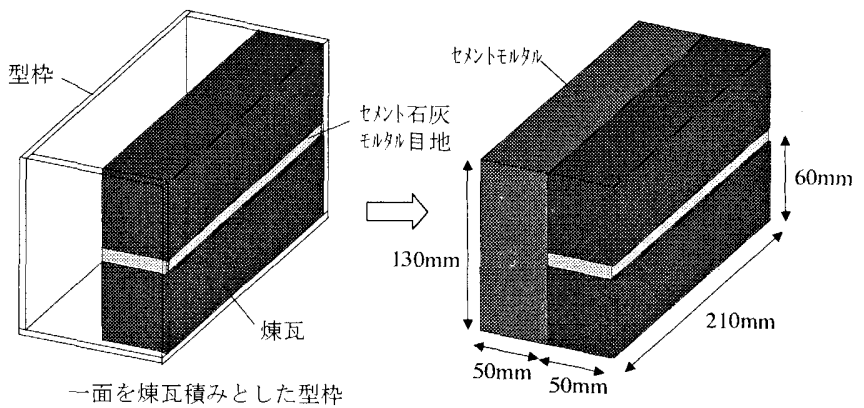

図 11 モデル試験体の概要

表 2 試験体の条件および調合

\begin{tabular}{|c|c|c|c|c|}
\hline $\begin{array}{c}\text { セメトモルタル打設 } \\
\text { の有無 }\end{array}$ & 棟瓦の位置 & \begin{tabular}{|c} 
飽和体積含水率 \\
$\left(\mathrm{cm}^{3} / \mathrm{cm}^{n}\right)$
\end{tabular} & 目地モル夕ルの調合 & セメンモルタにの調合 \\
\hline \multirow{2}{*}{ 有 } & 上段 & 0.16 & \multirow{4}{*}{$\begin{array}{l}\text { セット: 石灰: 砂 } \\
=1: 2.5 \text { (容皘比, } \\
\text { 砂: }: 2.5 \mathrm{~mm} \text { 以下) } \\
\text { 水/石灰 }+ \text { 七ット =0.6 } \\
\text { (重量比) }\end{array}$} & \multirow{4}{*}{$\begin{array}{l}\text { 水セジ比 }=0.6, \\
\text { セント: 砂 }=1: 2.5 \\
\text { (砂: }: 5 \mathrm{~mm} \text { 以下) }\end{array}$} \\
\hline & 下段 & 0.16 & & \\
\hline \multirow{2}{*}{ 無 } & 上段 & 0.17 & & \\
\hline & 下段 & 0.17 & & \\
\hline
\end{tabular}

2) 石灰：消石灰 (密度 $\left.0.57 \mathrm{~g} / \mathrm{cm}^{3}\right)$

3）飽和体積含水率：24 時間冷水に浸漬㖟の含水率

\section{2 試験概要}

図 12 に試験概要を示す。第 4 章と同様に試験体の観察面と上面 の煉瓦面以外にエポキシ樹脂を塗布し、上面の棟瓦部分からのみ水 が浸透するようにした。試験では、水を試験体上部の水溜に注ぎ入 れ、24時間湿潤状態にした後、水溜の水老抜き、72 時間乾燥した 後白華現象老観察した。これを 1 サイクルとして繰り返し 10 サイ クルまで観察索行った。乾燥中は水溜に蓋を!て、観察面からのみ 水分が蒸発するようにした。な㧍、試験は $20{ }^{\circ} \mathrm{C} 、 60 \% \mathrm{RH}$ の恒温恒 湿槽内で行った。比較のため、セメントモルタルを打設しない試験 体についても試験を行った。

また同時に、図12 に示寸ように上段棟瓦、下段棟瓦に製作した TDR プローブを観察面から $25 \mathrm{~mm}$ の位置に設置し、促進試験中の 各煉瓦の含水率の経時変化を測定した。

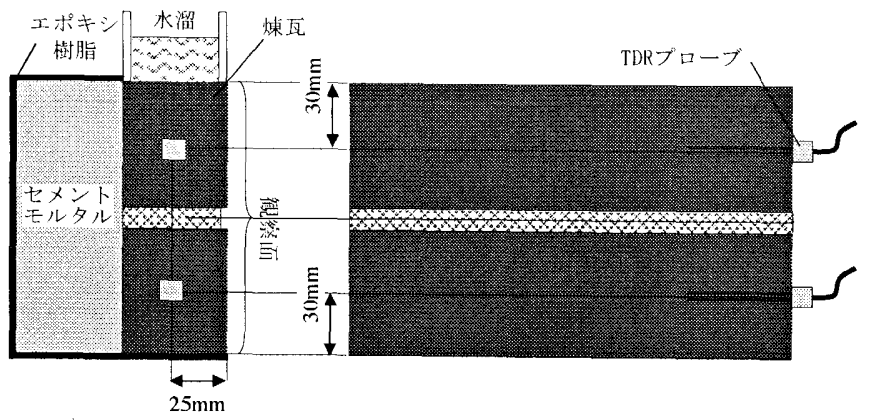

図 12 促進試験の概要およびTDR プローブの設置位置

\section{3 白華現象の観察結果}

試験結果を写真 5 に示す。また、試験結果の写真を二値化した画 像から白華面積を計算した結果を図 13 に示す。棟瓦積みの湿潤・ 乾燥の繰り返しにより白華現象が顕著になることがわかった。また、 セメントモルタル打設無しの試験体にも白華現象が引き起こされて いることがわかる。これは、セメントモルタル打設無しの白華現象 は目地モルタルや煉瓦中の可溶塩類によるものと考えられる。 さらに、棟瓦の位置によって白華現象の表れ方に明暸な違いが見 
られ、白華現象が顕著であった棟瓦はセメントモルタル打設有りの 上段棟瓦であった。これは、煉瓦の位置により含水率が異なるから である上考えられ、上段の煉瓦がより含水率が高くなった結果、七 メントモルタルから多くの塩類が溶解し、棟瓦表面に移動したため であると考えられる。

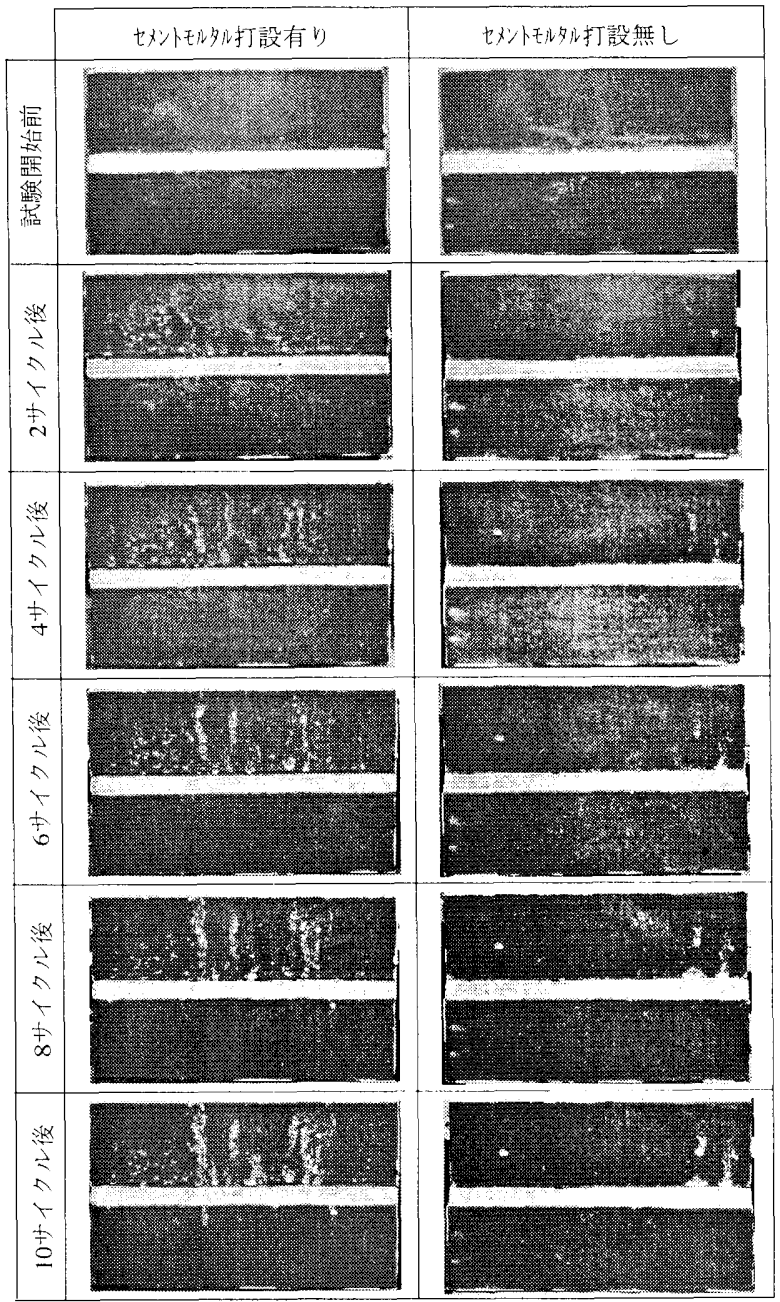

写真 5 観察結果

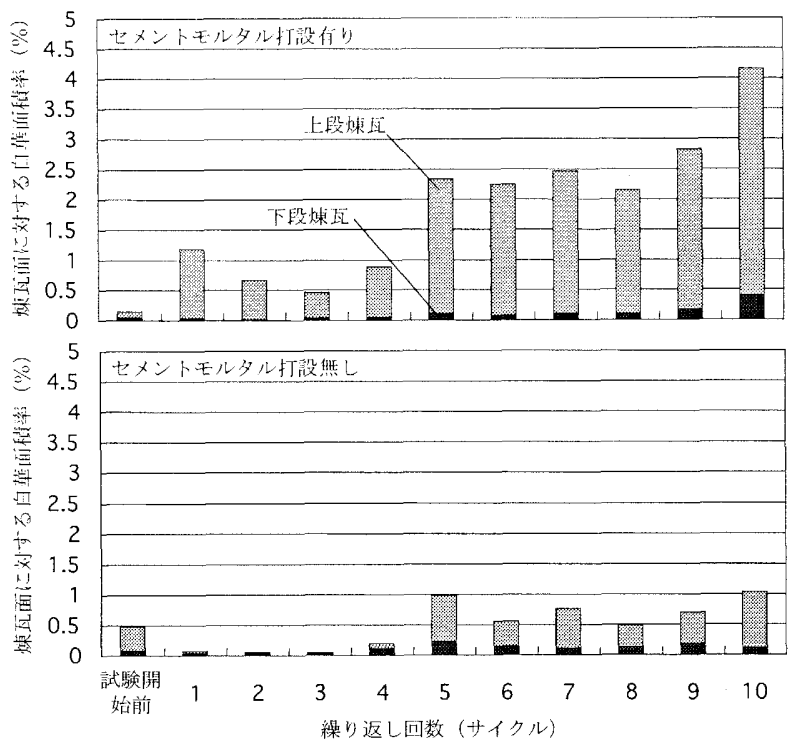

図 13 白華面積率の変化
7. 4 棟瓦の含水率の経時変化

図 14 に各煉瓦の含水率の経時変化示す。セメントモルタル打 設有りとセメントモルタル打設無しの試験体の含水率変化はほぼ同 様な変化を示した。つまり、上段の煉瓦の含水率は湿潤状態でほぼ 飽和状態になるのに対し、下段の棟瓦の含水率は常に 1 2 Vol\%程 度であり、低い含水率であることがわかる。また、上段の棟瓦は湿 潤乾燥の繰り返しにより試験中の含水摔が約 $6 \mathrm{Vol} \%$ から飽和状態ま で大きく変化したが、下段の煉瓦は含水率がほぼ一定の状態を維持 していることがわかる。これは、使用した目地モルタルの透水性が 棟瓦よりも小さいためであり、下段の煉瓦まで水分が移動しないた めであると考えられる。

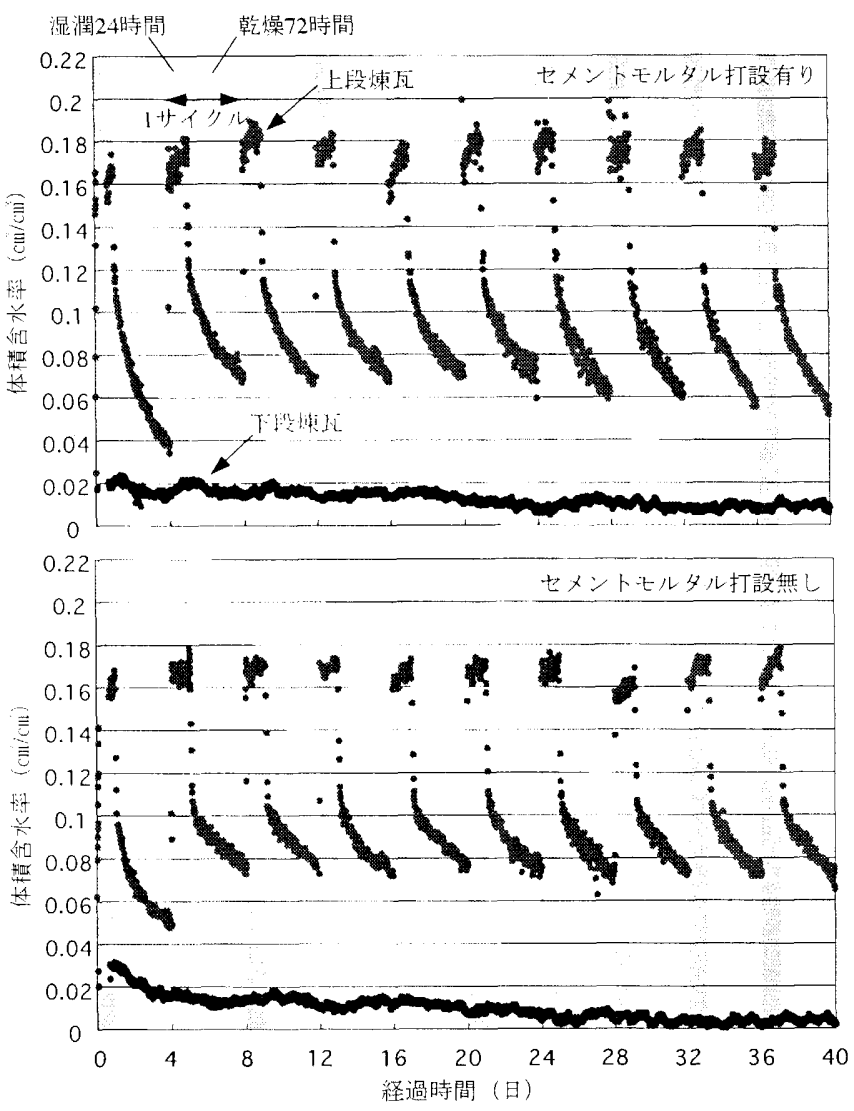

図 14 各棟瓦の含水率の経時变化

\section{5 棟瓦の含水率と白華現象との関係}

棟瓦表面の観察結果では、白華現象が最も顕著に観察された煉瓦 はセメントモルタルを打設した試験体の上段煉瓦であったことから、 白華現象が引き起こされる条件としては、煉瓦とコンクリートが接 触していること、含水率が高くなること、含水率変化が大きいこと (湿潤・乾燥を繰り返すこと) が举げられる。

上段棟瓦の場合、含水率が $4 \sim 5 \mathrm{Vol} \%$ 以上になったため、顕著な 白華現象が引き起こされたと考えられる。先述したようにその範囲 では液状水の移動が可能であるため、液状水に溶解したセメント塩 類もまた移動することができると考えられるからである。逆に下段 棟瓦の場合、含水率が常に 4 5 Vol\%以下の範囲であり、棟瓦内部 の水分移動は水蒸気による移動が主体となり、棟瓦表面まで塩類が 移動することがなく、白華現象はほと九ど引き起こされなかったと 


\section{考えられる。}

本研究で使用した煉瓦に関して言えば、液状水が移動できる含水 率の範囲、寸なわち塩類が移動できる含水率の範囲を考慮すると、 白華現象が引き起こされる含水率の目安は 4 5 Vol\%程度であると 考えられる。

\section{8、棟瓦壁体の含水量の観点からの毛華防止対策の考え方}

以上の実験結果から、歷史的棟瓦造建造物に対し鉄筋コンクリー 卜補強を行う場合、以下の上うな白華防止対策が考えられる。

煉瓦壁体の含水率を低い状態を保ち、からその変化を小さく寸る ような処置をする、亦るい注、含水率が高くなるような箇所ではコ ンクリートとの接触を避けるなどの対策が有効であると考えられる。 前者の場合、建造物在室内で保存寸る場合には考光得る。また、 屋外であっても短期的には覆いを設置し雨水を遮断することも可能 であると考えられる。しかし、普通建造物は屋外に保存することに なるため、長期的に含水率老低く保つことは困難であると考えられ る。したがって、後者のようなコンクリートとの接触を避けるとい う対策が現実的である。特に、雨水により濡れやすい箇所には新設 する鉄筋コンクリート躯体が接触しないような設計段階での配慮が 必要であると考えられる。

実際に行われている白華防止対策として、コンクリートと接触す る箇所に揖いて煉瓦壁体に事前にプライマーを塗布卞る処置が行わ れる事例がある。この方法は短期的には有效であると考えられるが、 長期的に効果を持続できるかどうかは検討が必要である。より水遮 断性があり、しかも接着性に優える工法の採用が望走れる。

\section{9. 結論}

鉄筋コンクリート補強された歴史的棟瓦造建造物の白華現象に関 して以下の知見が得られた。

1）白華現象を再現寸るための促進試験方法について検討し、湿 潤・乾燥の繰り返し試験により促進的に白華現象を再現するこ とができることを示した。

2）モデル壁体を使用した促進試験の結果、白華現象が引き起こ される条件として、煉瓦とコンクリートが接触していること、 含水率が高くなること、含水率変化が大きいこと（湿潤・乾燥 を繰り返すこと）が挙げられる。

3）棟瓦の含水率が 4 5\%以上の範囲では、棟瓦内部の水分移 動の主体は液状水となり、それ以下の範囲では水蒸気となるこ とを明らかにした。したがって、含水率が 4〜5Vol\%以上とな る棟瓦においては、塩類が液状水とともに表面に移動すること が可能になるため、顐著な白華現象が引き起こされると考えら れる。

4）白華現象の防止対策としては、棟瓦壁体の含水率を低い状態 を保つ、あるいは含水率が高くなる箘所では、コンクリートと の接触を避けるなどの方法が有効であると考えられる。

\section{参考文献}

1）酶澤英和・金多潔、「鉄骨構造の保存工学八の応用一洋風棟瓦造の重要 文化財建造物の耐震補強について一（その 1)」、カラム113 号、pp.71-78、 1989.7

2)西澤英和・金多溸、「鉄骨構造の保存工学入の応用一洋風棟瓦造の重要 文化財建造物の耐震補強について一（その2)」、カラム114 号、pp.21-28、 1989.10

3) Chin, I.R., "Spalling of Brick," Masonry: Opportunities for the $21^{\text {st }}$ Century, ASTM STP 1432. D. Throop and R.E. Klingner, Eds., ASTM International, West Conshohocken, PA, 2003, pp.97-113

4) Chin, I.R., and Petry, L., "Design and Testing to Reduce Efflorescence Potential in New Brick Masonry Walls," Masonry: Design and Construction, Problems and Repair, ASTM STP 1180, J.M. Melander and L.R. Lauersdorf, Eds., American Society for Testing and Materials, Philadelphia, 1993, pp.3-21

5) Isberner, A.W., "A Test Method for Measuring the Efflorescence Potential of Masonry Mortars," Masonry : Research, Application, and Problems, ASTM STP 871, J.C. Grogan and J.T. Conway, Eds., American Society for Testing and Materials, Philadelphia, 1985. pp.27-37

6) Harris, H.A., "A Method to Determine Efflorescence and Water Permeance of Masonry Mortars," Masonry: Research, Application, and Problems, ASTM STP 871, J.C. Grogan and J.T. Conway, Eds., American Society for Testing and Materials, Philadelphia, 1985, pp.88-100

7) Tomassetti, Albert A., "Problems \& Cures in Masonry," Masonry: Components to Assemblages, ASTM STP 1063, American Society for Testing and Materials. Philadelphia, PA. 1990, pp.324-338

8) Grimm. C.T., "Durability of Brick Masonry: A Review of Literature," Masonry: Research, Application, and Problems, ASTM STP 871, J.C. Grogan and J.T. Conway, Eds., American Society for Testing and Materials, Philadelphia, 1985 , pp.202-234

9) Ritchie, T., "Study of Efflorescence on Experimental Brickwork Piers," Journal of the American Ceramic Society, Columbus, Ohio, Vol.38, No.10, Oct. 1957, pp.357-361

10) Young, J.E., "Backup Materials as a Source of Efflorescence," Journal of the American Ceramic Society, Columbus, Ohio, Vol.40, No.7, July 1957, pp.240243

11)「レンガ造建築在鉄骨で補強 保存工学に新ボキャブラリ一加わる」、 日経アーキテクチュア、1982.3.15号、Pp.52-57

12) Topp, G.C., J.L. Davis, and A.P. Annan. Electromagnetic determination of soil water content: Measurements in coaxial transmission lines. Water Resour. Res. 16, 1980, pp.579-582

13）八幡敏雄:『土壌の物理』、東京大学出版会、1975

(2004年 6 月29日原稿受理，2004年 9 月28日採朋決定) 